\title{
'The Racial Inferiority of Anglo-Saxons'
}

\section{Britain in the Nordicist/Mediterraneanist Debate}

HE FASCIST REPRESENTATION OF Britain in racial terms has
received little attention in the literature. ${ }^{1}$ No previous study has taken
into consideration the fact that Italian racism was divided among factions with different worldviews, goals, allies and enemies, and how that influenced the choice of the themes used by this racist discourse. Whereas previous works treated the racist attitude towards Great Britain as monolithic, this work aims to provide a more detailed and nuanced reconstruction of the racial criticism of Britain in the period during which it flourished, 1938-1943. The double interpretative goal adopted is to identify both the origins of the propaganda's themes and the reasons behind the diverse stances adopted by different racist personalities. This essay will focus on the analysis of British racism as perceived by Italian racists, torn between considering it a good example because of the firm racial consciousness it created and the impressive achievements of British imperialism, and criticising it because of its excessive harshness. The focus will then shift to the origins and peculiarity of the various racist factions that emerged during the late I930s and the war years. The racial image of the British emerging from the analysis is fragmented and at times inconsistent, changing again and again until the end of the regime. This essay will analyse how the various factions each developed one or more understandings of the 'racial nature' of the British, both according to their scientific (or, more accurately, pseudoscientific) postulates and, often, to the political opportunity within the context of the struggle with the rival factions.

\section{Italian and Fascist Racism}

While forms of both spiritual and biological racism had existed in Italy since the nineteenth century and a number of Italian scholars adhered to northern 
European racial theories, the fact that people like de Gobineau and Chamberlain, the fathers of biological racism, held the Italians in contempt alienated most Italian intellectuals. ${ }^{2}$ Even when, with the development of anthropology, eugenics and archaeology, the European debate about race was dominated by a more 'scientific' approach, the strong antiscientific prejudices held by the idealistic cultural élites of Italy meant that cultural, or spiritual racism (as well as Lamarckian, or environmental, genetics) was always more popular in the country. Internationally, Italy was weak compared to other European nations, and the great difference in the development of northern and southern Italy inspired many racist Italian thinkers to speculate on racial explanations for these differences. ${ }^{3}$ Eventually, in the early twentieth century, two schools emerged: one that identified the Italians with the Aryans and one that claimed they were Mediterraneans. The first assumed that the Italians were part of the dominant ethnic identity of northern Europe, implying that current Italian weakness was the consequence of the country (and of course the southerners in particular) being 'racially contaminated' by inferior races. The second insisted that, far from being Aryans, the Italians were part of the (recently 'discovered') Mediterranean race. The hugely influential anthropologist Giuseppe Sergi was the most important of the Mediterraneanists: he claimed that the Mediterraneans, being an independent group themselves, were the greatest of the races and denied that the Aryans (who, until recently, had been unable to develop civilisation) had a meaningful influence on European history. ${ }^{4}$ Anti-Germanic and anti-Nordic feelings peaked during the Great War, as reflected in Mussolini's writings at the time. ${ }^{5}$ However, his new Fascist comrades also influenced the future Duce's early racial ideas. While Mussolini praised the Latin race in one of his speeches, he also deplored the current state of Italy, and soon absorbed much of the Nationalists' stance on regenerating Italy. Convinced of the necessity of improving the Italian people by transforming their character along Fascist lines, he made it clear, even before his rise to power, that eugenics must play a role. However, it was not until 1927 that he started to introduce measures aimed at increasing the 'health' of the nation, by encouraging physical activity, as well as fecundity, with the creation or improvement of prenatal and maternal support structures, increasing criminal sentences for those involved in abortion and taxing bachelors. ${ }^{6}$ The Catholic Church supported these policies, and for ten years Mussolini appeared convinced that such policies were proving successful. ${ }^{7}$ Increasingly racist towards people of colour, after the proclamation of the Empire in 1936 Mussolini began outlining an apartheid system in East Africa and was incensed by accounts of frequent miscegenation there. ${ }^{8}$ The development of an Italian 
Fascist racial doctrine was the consequence of the Duce's frustration with the apparent failure of his attempts to build a 'Fascist New Man' through both political indoctrination and eugenics programs.

German-style racism was quite unpopular in Italy in the mid-1930s and would remain so for most of the population. In 1934, during a period of temporary crisis with the new Nazi regime in Germany, Mussolini openly ridiculed Nordicism and German claims of racial superiority. In 1936, Sergi once again championed the Mediterraneanist cause with a book entitled The Britons: Mediterraneans in the North of Europe, in which he claimed that the glories of the British Empire came from the Mediterranean origins of part of its people. ' In his book, Sergi stated that the Mediterranean presence in the British Isles preceded by far the various other peoples, like the 'Celts, Scandinavians, Wikings [in English in the text] and Normans, Danes, Angles, Saxons, pirates and thieves, who brought enormous damages to the population and the territory and caused fierce and bloody civil wars as well as a century-long, deep anarchy.' While they probably were not the first inhabitants, the Mediterranean Britons (linked with the Iberians) still had a major ethnic presence in the islands. The successive invading peoples were indeed little more than 'a few hundreds of men that suddenly landed on the British coasts assaulting and submitting the [native] inhabitants like the fierce pirates they were,' who were unavoidably assimilated by the indigenous population. ${ }^{10} \mathrm{His}$ conclusion was that 'it is possible to trace, in the British population, an archaic base common with many other populations of Europe, Greece, Italy, France, Spain with [sic] Portugal, as well as with other populations of Central Europe.' ${ }^{11}$

However, and surprisingly, when Mussolini decided to create his own brand of racism, he did not make use of Italian Mediterraneanism, but did so by synthesising the concept of Romanità with the Nordic Aryan myth. Unsatisfied with the progress of his attempt to transform Italians, convinced that the myths of Romanità and Mediterraneanism had proven insufficient for his goals, he thought that Nordic Aryanism could provide Italians with a militaristic racial model. Mussolini's contempt for southern Italians and his long-time anti-Africanism probably made such a choice easier, and in 1938 the Duce privately stated that he himself was Nordic. ${ }^{12}$ Mussolini tasked the young anthropologist Guido Landra with writing the 'Manifesto of the Racial Scientists' in 1938. ${ }^{13}$ The Manifesto sported a scientific approach to the problem of race. While Romanità could be kept with reservations, Landra's Nordicist racism replaced concepts like Latinità (Latin-ness) and Mediterranean identity with Nordic-Aryan myths. ${ }^{14}$ Supported by the anti-Semitic faction of the Catholic Church, the racial campaign singled out Jews, useful targets because the stereotypes surrounding them were close to what Mussolini wanted to fight in the Italian bourgeois class. The racial 
laws did not, however, signal the final victory of the Nordicist faction. Mussolini himself seems to have regretted his support for this brand of biological racism and the Mediterraneanists fought back, reclaiming much of their lost influence under the banners of spiritual racism and Catholicism. The struggle did not cease until the end of Fascism and around 194I a new faction, the one led by spiritual Nordicist Julius Evola, emerged. ${ }^{15}$ With consensus proving impossible, only German occupation of the country made the pro-German faction, led by the long-time anti-Semite Giovanni Preziosi, the force behind the harshly anti-Semitic Fascist policies of the Republic of Saló in 1943-1945.

\section{Understanding the English and Their Racial Policies}

The first 'anthropological' analysis of the British people in the Fascist press can be found in the article 'The discovery of the English' by Curzio Villa in Gerarchia in January 1938. Villa stated that 'to understand the English character means to understand England, it means to anticipate the developments of English politics and, somehow, foresee its future consequences.' The elements that had contributed to the formation of the 'unmistakable physical and spiritual' traits of the English had been ethnic, geographic and ideological (i.e., the Puritan idea). The English 'race' was the expression of an 'obscure mix of races coming from the Baltic that settled [in] the great islands' and formed its character after the invasion of the Normans. Villa summed up the supposed English national character in a few essential traits: the preponderance of pragmatism and utilitarian realism, which subordinated theories, ideals and feelings to interest and reason, as well as a perceived necessity for cooperation and a tendency toward social organisation. The latter resulted in a strong sense of collective discipline. Other features were the ritual concept of life (as shown by the rigid system of ceremonies, traditional costumes and vocabulary in British public life), the idea of respectability and team spirit. The last, remarkable, trait was the deep belief in the superiority of the English people over every other. The reasons for such a hubris (which Villa considered one of the 'funniest features of the English character)' were both historical (long isolation) and religious (dating back to Cromwell and his conviction of the divine mission of the English people). The key to the English ability to combine their spiritual side with their constant pursuit of self-interest was hypocrisy. Unable to understand abstractions and great intelligent ideas, the English were gifted with a formidable instinct but lacked intelligence, while their civilisation was all appearance, characterised by empiricism, greediness and personal interest. The English national character, according to Villa, 'was completely subject to instinct and nature. ${ }^{16}$ Interestingly 
enough, while successive Fascist criticism of Britain corresponded with some points of Villa's analysis, the supposed English tendency towards social cooperation and discipline was consistently denied by many racist scholars, to the point of describing the British as unable to even conceive of the concept of community. Furthermore, later authors claimed that the British way of life, far from being 'subject to instinct and nature,' was indeed antinatural and antibiological.

A few months later, Mussolini launched his 'Reform of Customs' (one of the most derided consequences of which was the ban on the handshake, which was considered soft and 'Anglo-Saxon'). ${ }^{17}$ His racial campaign followed, culminating in the 1938 racial laws. Mussolini's obsession with the problem of miscegenation was soon mirrored in La Difesa della Razza. ${ }^{18}$ Already in the third issue, it was noted that the French colonial model, encouraging massive movements of metropolitan colonists to the colonies, had as a consequence the spreading of miscegenation. ${ }^{19}$ The British, in contrast, only allowed a limited number of white women to move to the various countries of the Empire. ${ }^{20}$

The first article focusing explicitly on Britain appeared in La Difesa in November 1939, under the title 'British Racism.' According to the author (identified only as A.L.), the British Empire and people were extremely racist. Furthermore, British racism was described as unique, 'aprioristic and integral,' and sprung from the Englishman's notion of his own absolute ethnic superiority compared to all other men living on the Earth, be they white or coloured. ${ }^{21}$

While living an attractive way of life, characterised by the absence of frugality and based on comfort and relaxation, the Briton's basic notions of British superiority made him unable and unwilling to see what was wrong in his own home. He was, however, also a harsh ruler. Abroad he posed as a 'silent and severe master, greedy merchant or merciless creditor, he was devoid of sympathy for any foreigner.' Never loved, he was nonetheless respected, sometimes even admired, but often hated. The article described how brutal British racism was concerning its colonial subjects. ${ }^{22}$

La Difesa, however, was a racist magazine, which responded to Mussolini's perceived necessity to construct a racial identity for the Italian people. The very characteristics of the British described in the article were quite close to what Mussolini had declared his desire to turn the Italian into when he told Ciano the Italians had to learn 'to be less "nice," to become hard, implacable, hated. That is, masters. ${ }^{23}$ The author seemed to show respect for the British racial attitude towards their inferior subjects:

The Briton rules, we have to admit, with a handful of white men over vast lands, that is because of his energy and his bravery: he is extremely severe 
when he asks for obedience, implacable when suppressing: the Briton does not oppress the native, instead leaving him the full freedom to follow his own customs, but $[.$. . $]$ he does not give him anything back. ${ }^{24}$

Furthermore, the British (meaningfully here called Anglo-Saxons) used to get rid of the races they deemed unassimilable. ${ }^{25}$ This inconsistency regarding British colonialism was inherent in Fascist rhetoric and was usually solved by claiming that it was British hypocrisy, not British violence, that was despicable. The following passage regarding the British perception of Jews is an example of that kind of reasoning:

Great Britain is not racist, or so it claims, but does not allow Jews in the main public services or among its high officers. An Anglo-Saxon asked whether an Israelite is an Englishman, will simply and calmly answer that he is not English, but an Israelite. With the same aplomb he will however declare himself an antiracist! ${ }^{26}$

In this early phase, some Nordicists seemed to consider the British more as an example to follow than an enemy to despise. In the same issue, in an article supporting alimentary autarchy and claiming that it was the law of nature that the carnivore is the master and the herbivore the servant, Giuseppe Lucidi (a quite unknown signer of the 'Manifesto' who became a proliferous contributor to La Difesa) remarked how 'a few tens of thousands of well-fed, carnivorous Englishmen manage to rule over two hundreds millions of Indians. ${ }^{27}$ The ruthless British attitude was an example of what was needed for a superior race to rule over large, inferior, masses of coloured people. The Nordicists were, in this case, close to the Nazi perception of British colonialism. Hitler and many others in Germany were convinced that brutality in the colonies and in war was a key feature of the British national character. Even Allied victory in the Great War, according to many Germans, had been mostly due to the British lack of moral scruples in starving the German nation through the blockade. ${ }^{28}$

Guido Landra fought furiously against his Mediterraneanist rivals (and in this case against their Lamarckian beliefs) when he wrote an article entitled 'The Environment Does Not Change the Race's Nature' some months later. Rejecting the idea that it was the geographical position that made the fortune of great civilisations, he claimed that there were islands far better placed than Britain, and places far more suited for the foundation of a city than Rome. ${ }^{29}$ He concluded that, given the right racial attributes, it is men who defeat the environment, and not vice versa. Once again, Britain was considered a positive example, in this case even compared with Rome. 
Other contributors to La Difesa were far less enthusiastic about Britain and its imperial methods. One was the journalist, director and cinema critic Antonio Petrucci. In an article, he described the Italian relationship with its imperial subjects as the right balance between the excessively friendly approach and the far more brutal British one.

The pride in their own superiority, exasperated by an education that is based on the famous motto according to which the Negroes begin just below the Channel, makes of the English who moved to the colonies an example of the second [excessive brutality] case. ${ }^{30}$

Petrucci criticised British brutality once again a few months later, claiming that while British colonialism had been somewhat admirable, the British ideology of Anglo-Saxon racial superiority had been the cause of the extermination of the natives, especially in the Dominions. ${ }^{31}$ Later, he talked of the 'failure of the British colonization in Africa,' caused by wild mercantilist imperialism. According to Petrucci, the British were proving unequal to the responsibilities the superior white race had concerning its supposedly inferior subjects. ${ }^{32}$

Lidio Cipriani, one of the original scientists who signed the Manifesto and a die-hard Nordicist, surprisingly shared Petrucci's point of view. Cipriani was an anthropologist whose area of expertise was the African races. While thoroughly convinced of the inferiority of the A frican peoples, ${ }^{33}$ he also believed that British colonialism was predatory and exceedingly violent. In December 1940 he wrote in La Difesa about the different races' methods of conquest and ruling. He stated that while the Italians were fair and humane rulers (as proven by 'the chubby faces of the kids born after our annexation') the British Empire had been by far the most brutal of the colonial powers, whose 'inhumane methods, applied as they were on a huge scale, decimated or destroyed the harmless indigenous populations all over ample territories.' The Italian people, instead, thanks to their 'ancient civilization that Italy enjoyed because of its racial features,' were incapable of mistreating the weak and of being 'insincere. ${ }^{34}$

\section{Explaining British Defeat: the Nordicist Reaction to Britain's Difficulties in the Early Phase of the War}

The events of the first year of the war were to greatly influence the racial discourse concerning Britain. In March 1940, in the middle of the uncertain period before the German attack in France that made Mussolini decide to join the war, Silvio Landra, Guido's brother, wrote an article entitled 'Two Peoples 
Struggling,' in which he analysed the two main belligerent nations: Germany and Britain. Landra claimed that the struggle between these two powers was not a racial one, for the Germans and English were, if not brothers, at least cousins. He argued that Britain was 'inhabited by a people that was created out of the mixture of the Saxons, the Angles, with elements of Celtic and also Mediterranean origin [...] as well as of the invasions of the [Scandinavian] Normans and Danes.' Celtic populations still lived in some regions of the country, and the differences in both looks and character between the Germanic and Celtic elements, where the mixing had not occured, were easy to spot. Describing the English, Landra wrote that 'not denying his own good qualities as a worker, mariner and manufacturer, it must be noted that all his activities are dominated by egoism and cold calculation.' The author described the Germans in a better light, without, however, trying to predict which side would prevail..$^{35}$ The article was relatively balanced, and reflected both the difficulty in racially attacking the English without involving the Germans and the uncertainty regarding Italy's place in the conflict. In the following issues of La Difesa, not much attention was given to Britain. Things changed after the Allied defeat in the Low Countries and France. In the 20 June issue, after Italy joined the war, Guido Landra tried to explain through a Nordicist lens the German triumph and the Allied disaster. Defeated France, inhabited by Celts, had no right to call itself a Latin nation: ${ }^{36}$ The struggle against Britain had its own clear racial character as well. The island, originally Celtic, had been repeatedly invaded by different peoples, all of which were of Nordic stock. These racially superior elements were the same and, as in other continents, had contributed to the creation of new nations. In 'Old England,' instead 'they had assumed a completely oligarchic and mercantile form.' It was therefore necessary that 'a new great Nordic invasion would happen to England, and that other peoples would reorganise it in a more civil way the rule of the seas and the continents. ${ }^{37}$ The problem was the decline of the Nordic element that had built the British ruling class. It is remarkable that the first analysis that sought to explain the crisis of Britain through a racial lense came from the same author, Landra, who would later vehemently resist the racial demonisation of the English. In the same issue, Ubaldo Nieddu wrote extensively about the connections between theatre, poetry and race, describing Shakespeare as an author who had been able to fascinate the public of every age and country thanks to his connection to his race. Writing about 'the most Latin of the Latins,' he had given Caesar that 'sense of reality' that was typical of the English race but also of the Ancient Romans. At this point Nieddu, probably realising that such a positive comment about the nation Italy had just declared 
war on was not acceptable, added that, in light of recent political events, such a 'sense of reality' was no longer a British racial attribute. ${ }^{38}$

\section{National Sickness, Sexuality, Degeneration and Antiracial Ideologies}

The theme of the weakness, decline and degeneration of the British race had consistently appeared on the pages of La Difesa since before the war. Antonio Petrucci, anti-British as ever, criticised refinement and high standards of life as the cause of decline of the strong races. He was clearly talking of Great Britain in particular, since he wrote that 'the British soldiers who brought all the supremacy of the Union Jack over the world, certainly did not have the supplementary portions that Hore-Belisha's soldiers can enjoy today. ${ }^{39}$

The harsh anti-Semite Armando Tosti was one of the sharpest anti-British contributors to La Difesa. In an article entitled 'British Antiracism,' he linked the ideas of the eighteenth-nineteenth century demographer Thomas Robert Malthus with the ones of his coeval economist David Ricardo, who he called 'English ambassador[s] of a Divinity hostile to humans.' Both authors, according to Tosti, expressed a worldview that inhibited procreation. The consequence of what he called 'these magnificent ideas' was that 'it is not possible, in Britain, to address the problems regarding the continuity and health of the race.' Tosti quoted Trevelyan (who was himself an ardent admirer of Mussolini), stating that if Great Britain had been a great nation in $185 \mathrm{I}$, the opposite was true today. ${ }^{40}$ The more recent generations had experienced moral, spiritual and intellectual degeneration, also caused by the crowded environments in which they lived, by alcohol and lack of fresh air. Further proof of such degeneration was the 'alarming cases of homosexuality, not limited to the famous ones of Lord Douglas and Oscar Wilde.' Tosti added that, according to nineteenth century authors, British soldiers were ready to sell their bodies for money and that the British people saw no difference between homosexual and heterosexual relationships. According to Tosti, 'if we want to have the right understanding of [...] the sexual idealism of England, one can look for it in the writings in which Edward Carpentier [sic] (again an Englishman!) explained and almost glorified sodomy!'¹

Women and children were the principal victims of British antiracism. Violence against women was endemic and children were subject to corporal punishment (which Tosti did not consider useful for the health of the race). The British often employed still painfully young children in the mines and in other menial labour, in terrible health conditions. British children were 'usually in bad 
condition, pale, sickly, and in general they look like a generation whose physical strength is increasingly disappearing.' The British people were 'ugly' and more vulnerable to illnesses than other populations. Tosti believed that antiracism was a way to mistreat a people's own race. He concluded that 'the step from antiracism to mistreating other races was short.' The oppressed Irish (whose race was clearly different from the British) and the subjects of the British colonies were examples of such brutality. Hence, the British people, who had so many flaws in their own race and mistreated other races, could not hope to be relevant in Europe, and could not, in the name of a nonexistent civilisation, rule the world. ${ }^{42}$

British sexuality had been previously discussed by the journalist Marco Ramperti in La Stampa, in which he argued that the undying anti-Italian hatred of the British had a sexual origin and came from the deep envy the English harboured for Italian vigour. ${ }^{43}$ The British were homosexuals, according to the historian Alessandro Luzio, and were assisted in this by the 'conveniently placed thickets of Hyde Park. ${ }^{344}$ Much later, in July 1943, the important journalist and signatory of the Manifesto, Concetto Pettinato (who, almost sixty years later, was to be remembered by Indro Montanelli as an 'example of coherence and honesty') wrote in the same newspaper that 'Puritanism, methodism and moralism turned the English into a moral pachyderm reducing [. . . his faculty to answer to external excitations. ${ }^{45}$ Vice and cruelty were typical of the 'British Eros' and 'English love was always polluted by prejudice, regret, resentment or fear.' As for British feminism, far from meaning good relations between men and women, it 'meant a reciprocal rejection of the sexes' and was the cause of abuses and homosexuality. ${ }^{46}$ Another author talked instead of the British abuse of pornography, which brought much money to the pockets of Jewish pornography mongers. ${ }^{47}$

The two themes of the British 'antibiological' mind-set and the terrible influence those values had worldwide because of their export by Britain were later expanded by other authors. Regarding birth control, there could hardly have been an easier target for Fascist criticism. Ironically, the fears and goals of the British birth control, or Malthusian, movement were quite similar to those of the Italian Fascists who wanted to forge a new Italian race. Worried about a perceived decline in the racial quality of the population, and convinced that without a vigorous race, the Empire and the very survival of civilisation were in danger, the British Malthusians supported many measures, including the possibility of forced sterilisation, to improve the British race. ${ }^{48}$ While a longstanding racist newspaper like Il Tevere reported about British anxieties already in 1937, claiming (and in doing so echoing Mussolini's own preoccupations) that Italy was not safe either, these methods were not compatible with the ethos and goals 
of the Fascist regime. Italian authorities had always been suspicious about it, for more reasons than just the well-known opposition of the Catholic Church. ${ }^{49}$ Corrado Gini, who strongly influenced Mussolini's beliefs regarding the health of the Italian people, distrusted the 'economic' mind-set of neo-Malthusians and believed that birth control, once implemented, could escape the control of the authorities, potentially leading to the collapse of the nation. ${ }^{50}$ Already echoing Gini's thinking, in January 194I Nicola Pascazio wrote in Gerarchia that Malthusian propaganda (supported by the Anglican Church) had reduced the British birthrate to such a point that the 'vital power' of Britain was obviously declining. The consequences of birth control were to 'increasingly spread like an enormous abyss, at the roots of the biological and social building of the Empire. ${ }^{51}$ In June, Aldo Modica wrote that Great Britain, unable to take care of its own race, had seen the spreading of medical literature that encouraged the 'antibiological and antiscientific practice of birth control.' According to Modica, the racial decline of peoples that were 'too much civilised' was caused by the 'intellectual limitation of the births,' which caused a 'progressive diminution of genitalism,' meaning that mens' virility decreased and led to the eventual biological blurring of the differences between sexes. The unavoidable victory of the Axis was going to destroy such unnatural ideas and the new world was to be ordered according to a new, 'healthy, naturalistic ethics, in which peoples [would] find peace and harmony between matter and spirit, adoring the mother and the heroes, in one single symbol of equity and justice. ${ }^{52}$ In 194I the Corriere della Sera wrote that the reasons for British demographic decadence, which proved the end of any English role in Europe and the world, was not just the despicable Malthusian ideology but the idea that too many children were a strain for the wealth of the family. ${ }^{53}$ In July 1942, Il Tevere commented on the bleak demographic future of Britain, noting that while the number of dogs grew the number of children diminished. Facing the disappearance of their people, many Britons now advocated for the introduction of German style demographic control. ${ }^{54}$ The idea that British demographic decline was connected to the decline of Britain as a Great Power was not new. In September 1936, Mussolini had told Bottai that he had been sure of Britain's unwillingness to act in defence of Ethiopia. His certainty, Mussolini said, came from a study of British demographic statistics, which clearly suggested that Britain was a nation increasingly consisting of old men and women, while the number of youths diminished. He commented that 'such a phenomenon leads to the prevalence of the weak, the feeble, the peaceful, the conservative, over the energetic, the willing, aggressive, the innovator. Such an England would have no will to fight. And she did not fight.'55 
In January 194I, the Manifesto signatory Giovanni Savelli argued that the British antiracial ideology had a harmful influence on a world scale, producing a sort of 'racial atomism,' where, through artificial immigrations and the imposition of 'absurd borders' (one example was British Somaliland), British rule caused the fragmentation of racially homogeneous peoples. ${ }^{56}$

\section{From an 'Anthropological' to a Truly 'Racial' Discourse}

Between late 1940 and 1941, the fierce criticism of British racial policies and of their inability or unwillingness to preserve the health of their race often slipped into considerations that questioned the English race as a whole and sought to prove how decline was inherent not just in British choices or history but in its racial features. While the authors often echoed Landra's earlier argument, their condemnation of the British race was now much harsher and did not seek to separate the ruling class from the people. Furthermore, the Germanic invaders of the Isles were not exempt from criticism.

In October 1940, Bruno Damiani accused the British of having an 'anti-European and anticivil' mind-set. While he did not claim that the nature of the English character had only racial explanations (the article was, after all, entitled 'The English Children of Their History'), he took care to specify that distinguishing between the British people and the ruling class was useless, for 'Britannia is a multicellular animal, but the spirit and the brain are only one.' Damiani's discourse included clearly racial elements. According to him, 'the Celts of England and the Britons proved reluctant - both because of their intellective incapacity and hostility towards social institutions - to [assimilate] the Roman heritage.' Damiani wrote in Gerarchia rather than La Difesa, and was not reluctant to express somewhat anti-Germanic tones when he stated that 'those populations (the Angles and the Saxons) proved impervious to a sincere acceptance of the Christian spirit.' He added that 'the Germanic invasions of the Vikings later established a new unbalance' because of the lack of a Roman civilisation and Christian religion. ${ }^{57}$

Armando Tosti stated that British degeneracy, coming as it did from the ruling classes, had infected every country touched by the 'tentacles of England.' The topic of the degeneration of the English race was an old one, Tosti wrote in January 1941. 'I cannot help but think that degeneration is almost [... ] congenital to Britain,' he wrote, then proceeded to present a summary of British history that included cannibalism, thievery (quoting Hume, Tosti stated that before 1688 all Scotsmen were thieves), alcoholism, illiteracy (including among the ruling 
classes), torture, child abuse and murder. For Tosti, the ruling classes were still a clear example of British degeneracy. Lazy and hedonistic, they had 'set up a colossal banquet of pleasure, pride, vanity, they intoxicated themselves with all these poisons of the spirit. ${ }^{35}$

According to Tosti, before Fascism such degenerate Anglo-Saxons were a common sight in Italy, visiting the country, loving it when it was poor and picturesquely barbarous. British plutocracy itself had meaningfully contributed to the weakening of the English race, which was now unable to compete with younger and healthier races. 'In other words,' he concluded, 'the Anglo-Saxon race, which has lost any vitality, had, in recent times, increased its degeneration and exhaustion.' It was time for the Axis powers to bring it down once and for all.

One month later, Tosti wrote about the 'Psychic atavisms of the English race.' The article began as follows:

Nobody ignores that the principal characters of the English race are the habit to promise and not to keep their word; the opinion that everything is for sale; hence their ease with any kind of betrayal and the inclination to count on others to pull their chestnuts out of the fire. ${ }^{59}$

Other features of the British race were systematic hypocrisy and brutality. After a quite long summary of the examples of merciless violence in British history, Tosti concluded that the British race believed

it was the supreme flower of humanity, when it is instead only rich of the most brutal qualities of instinct, it's the race that does not contradict its psychic atavisms when, in 1940, it strafes field hospitals, kills women and children, uses the civilian population of the Italian and German cities as a military target. ${ }^{60}$

In June 1941, Tosti expanded his point of view in another article, in which he elaborated a curious explanation of the British national character. According to him, the British race had historically been unwilling to accept the sacrifices necessary to fight wars. This had racial explanations: 'indeed, in order to follow the political events and keep an eye on the major powers, the English are forced [in] to an intense cerebral activity, which explains, maybe even more than the weather, the spleen [in English in the text] they suffer of.' Such a tension, passed through the generations, had produced commercial and industrial speculation, which in turn had led to the establishment of an exploitative, lazy and conservative British capitalism. Capitalism and industrialism made them insensible to 
the ideal and moral values that permeated war. Despite its great successes, British capitalism had failed to vanquish its enemies (the other races, whose psychological attitude was so radically different from the English ones) and was now withering as a consequence of its lack of idealism. ${ }^{61}$

Furthermore, British capitalism had mongrelised the English race when it had allowed America to invade it. Americanisation, here meaning the penetration of American modernity, consumerism and race mixing, had deprived Britain of its national consciousness. The British people had never learned that

pain must be faced with calm and bravery; that war must be accepted as a law of our current human life; that the utopian social state described by modern utilitarian intellectuals, in which material pleasures would be the goal of life, is repugnant and hateful; that the great fundamental values are bravery and spirit of sacrifice; that the destiny of empires is tied to the development of the religious and altruistic sentiments in the human spirit. ${ }^{62}$

That was the reason Britain could not win the war against the younger peoples. The British race was a decrepit one, whose ephemeral victories had been achieved thanks to others and one that hoped to be saved by merchants from the other side of the Atlantic Ocean.

\section{The Nordicist Dilemma: the Led-Astray Anglo-Saxon}

The war against Britain and the United States, which many now identified with the war against the Anglo-Saxons, offered the rivals of the Nordicist faction a useful opportunity. Giovanni Marro, the most important of the Italian nativists, an emerging trend opposed to the other racist factions, managed to deal a blow to both the Mediterraneanists and the Nordicists when he harshly attacked Sergi's book I Britanni. Marro criticised Sergi's modernism, as well as his concept of a Mediterranean race. Furthermore, he could easily use Sergi's statements about the weaknesses of liberal Italy and 'the decadence of the Latin nations' to accuse him of anti-Italian sentiment. ${ }^{63}$ 'Infected' with the mark of Judaism by his friend Lombroso, Marro stated, Sergi had smeared the accomplishments of both Rome and the Italian race. However, Sergi's most hideous crime had been

the supreme insult of judging the 'English imperialism as perfectly similar to the Roman' and even to consider 'the English as the modern Romans, for convergence of origins, kin, of public life characters and of many other psychological, individual and social manifestations. ${ }^{64}$ 
When the United States joined the war, the Fascist press increasingly started to use the term Anglo-Saxon, both nations described as belonging to a single enemy race. Lidio Cipriani, as we have seen, had no problem writing harshly of British imperialism, but had to deal with the contradiction of being a key Nordicist writing for a magazine that was increasingly targeting the Germanic Anglo-Saxons as a race. Perhaps trying to find a solution, he wrote an article entitled 'Are the North Americans Anglo-Saxons?' His answer was negative. The growing presence of coloured peoples ("the Blacks in particular:" Cipriani stated that his long experience in Africa proved to him that Black people could not be civilised) represented a huge danger for the nation. The Americans were already a mixed people, and it was difficult to find an actual Anglo-Saxon in such racial chaos, despite the British having 'some merit' in the (brutal) colonisation of North America. Cipriani thought that the first English colonists were ethnically mixed as well, and so were their ancestors who lived in post-Roman Britain and even earlier:

We should not neglect to address the mix [that] happened between the Anglo-Saxons and the aboriginals of Britain: who were in turn far from uniform. Tacitus had indeed noticed short, swarthy men with curly hair who lived beside tall men with blond, wavy hair, very fair skin and blue eyes. ${ }^{65}$

Writing about Ireland, Cipriani mentioned the racial differences between the Irish and the English races, writing that while 'the English were generally tall, blond [...] long faced and headed, not vivacious and tending to insincerity,' the Irish were close to the Mediterranean peoples, both in somatic traits and in character. Indeed, they were 'usually shorter, dolichocephalic, dark eyed and haired, with a loyal and vivacious soul.' Despite these words, which could easily have been written by a Mediterraneanist, Cipriani took care to avoid any mention of the Nordic, or Germanic, nature of the English, only talking of the pre-Roman natives of Britain, whom the Caesar described as barbarous and cannibalistic. ${ }^{66}$

Guido Landra's reaction to the growing 'anti-Anglo-Saxon' tone of La Difesa was quite different from Cipriani's. In summer 1942, in an article regarding the importance of the study of chromosomes in order to understand race, Landra wrote that the English had a chromosomic Nordic element that was even purer than that of North Germans. ${ }^{67}$ As Aaron Gillette explains, in 1942 'Landra saw the increasingly desperate struggles of the Axis in World War II as part of a racial Armageddon. ${ }^{68}$ In July, he wrote that old, decrepit Europe had given up its hegemony over the world, as well as rejected its white heritage, by masochistically attempting to repress the vital energies of Italy and Germany. The conflicts against the 'mongrelised intellectual class' of France, the Anglo-Saxons and the 
Soviets could be defined as truly racial wars. However, while the war against the Bolsheviks was racial because they represented 'central-Asian barbarism' and were heirs of the 'Empire of the Tartars who had reached the Adriatic in a not too remote past,' the war against the Anglo-Saxons had a racial character just because 'when we fight England and the United States, we fight international Judaism that has turned those nations into its stronghold. ${ }^{69}$

While believing that the Anglo-Saxons had become puppets of the Jews, Landra did not think that the problem lay in their race. Nor had he completely given up his earlier appreciation for British imperialism: in September 1942, while writing on the issue of Italian racism in the colonies that Italy was to acquire from the British Empire, Landra still stated that 'we have to admit that they [the English] have a strong racial consciousness with regard to the natives.' He added that 'the Italian [people] will have to replace in certain zones, a people who knew very well the importance of the racial factors. ${ }^{70}$

In Landra's view, if 'the western countries, and the Anglo-Saxon countries in particular [were] in great decline, according to the racial point of view,' part of the reason was their urbanism. Given the rise of many Eastern peoples, still faithful to the land, the industrial development necessary to the Axis nations to contrast the Anglo-Saxons must not harm agriculture, which was essential for the defence of the race. Unlike the Italians, Anglo-Saxons, so proud of their strength, were now nothing but the 'asocial expression of the great cities they come from.' ${ }^{71}$

The final representation of Landra's apocalyptic worldview, and in particular of his opinion on Anglo-Saxons, can be found in a December 1942 article entitled 'Conflict of Races.' Here, Landra describes the races belonging to each of the two struggling alliances. Once again, the French were depicted as rotten and senescent and the Slavs were the Mongols of old. Regarding the Anglo-Saxons, Landra still could not condemn them, at least in racial terms, with the same harshness. While admitting that the British people were clearly in a state of senescence and decadence, he wrote that the roots of the Anglo-Saxon race were 'with no doubt a strong Nordic base,' which explained the past greatness of Britain and, partially, the reason for its successes. The problem was that, with time and because of the expansion of the British Empire, the racial character of the English people had deeply changed.

Landra's anxiety regarding the progress of the war is illustrated by his statement about

the Bolsheviks [that are] pressing with the forces of the renewed Tartary [...] the Anglo-Saxons [that are] unleashing against us the scum of all the 
continents. It is almost as if the Devil wants to destroy for good the ideas of good and beautiful from this earth. ${ }^{72}$

The predominant Jewish influence on their politics and society, the fact that they were conspiring with non-Europeans to bring Europe down and their racial decadence meant that the Anglo-Saxons could not be considered 'European peoples and of European civilization.' At the same time, however, Landra compared the Americans with the British, claiming that the former had very little in common with the latter who, 'for a long time, constituted a positive force for Europe.' It is not clear whether he eventually came to believe that the English were not a European people anymore; it is possible that, at the time of the fall of Fascism, he still had not found a solution for his dilemma.

\section{The Mediterraneanist Stance: The Insane Englishman}

Other promoters of racial beliefs did not have such problems. The Mediterraneanists could simply develop the most violent theories justifying the racial otherisation of the enemy. One example is particularly interesting in that it underlines both the extreme lengths to which this faction had gone to express their anti-British bias and the indifference to reality, and even simple intelligibility, of La Difesa's intellectuals. In April 1942, Giovanni Savelli wrote an article entitled 'Anglo-Saxon Racial Solitude,' a long, remarkably abstruse piece in which he addressed biology, psychology, anthropology, geography and history to articulate his own interpretation of the British racial character. Savelli's article was one of many similar pieces in which Fascist contributors to La Difesa or Gerarchia in particular investigated the supposedly peculiar psychology of the Anglo-Saxon race. These contributors tried to find a racial explanation for the traits of British (and American) societies, which were especially hideous to the Fascist mind-set and its emphasis on individualism. The pioneer of this genre had been the influential philosopher Francesco Orestano, who, in April 1941, in his Gerarchia article 'The Insane Englishman' had argued that a particular mental structure fundamentally separated the English (the term Anglo-Saxon was not fashionable yet) race from the Germanic or Latin ones. Once again, the English were accused of being irredeemably bound to the empirical world and of being incapable of elaborating 'general concepts.' This nature explained why the British, inherent believers in materialism and nominalism, were skilful in their manipulation of the physical world, where the inert nature was easy to manipulate, but traditionalist in the field of society, where human nature could not be as easily bent. 
The impossibility of British society expressing a superior moral order had the consequence of unleashing individual originality, tolerance and religious anarchy in the internal sphere, and shaping a faithless, chaotic foreign policy abroad. Lacking any sense of justice, Great Britain was unable to respect international treaties and was hence an enemy of the 'European Order. ${ }^{73}$

Savelli's article went even further. According to him, from the Early Middle Ages to the fifteenth century, English history had experienced violent struggles underlining the original racial tendencies that would be constant in later centuries. British history since the Tudors had revealed 'constant directions and impulses.' The formula that would be the core of the Anglo-Saxon world was discovered during the Tudor era and the strengthening of the monarchic institution. ${ }^{74}$ The Tudors had established their authority by aligning around them all the countless groups - municipal, associative, familiar interests - each of which had fought to keep its prerogatives during the Middle Ages and the Renaissance. Rather than creating order and hierarchy, the Tudors created a formula based on an elastic principle that, while proposing the myth of converging interests, was instead a 'bitter mechanic of interferences' that did not undermine the vitality of the groups. It was nothing more than the translation on a political level of 'a tendency towards moral and social atomism' typical of the English people and inextricable from the Anglo-Saxon psyche. If the Anglo-Saxon moral atomism influenced the British concept of politics, it was in turn influenced by the geographical position of Britain. Isolated in this 'moral microcosm' and unable to perceive the fullness of reality, the English turned to rational or instinctual models. Isolationist conformism hence characterised every field of Anglo-Saxon society:

Anglo-Saxon extremism [is linked] to the reactions and the bitter abandonments of a humanity isolated beyond a geographical fracture, which became, irresistibly and deliberately, a historical and moral one. On such a base, the destiny of the race is already defined. ${ }^{75}$

Any contact with the external world (in which political action gained its impulse from economic reasons) was to cause England massive instability. The detachment of the Anglo-Saxon from his islands was the archetypal 'adventure,' where the English fell among other peoples he did not understand. ${ }^{76}$ Adventurers and companies, these economic versions of the old 'clans,' formed the Empire. The fundamental characters of the race were codified in theoretical systems like Walpole's empiricism or William Pitt's political cynicism, Adam Smith's economic liberalism, or the parliamentary action of Peel and Gladstone, peaking in the establishment of free market, 'the complete expression of the atomistic 
dynamic of the race.' However, at this point, Anglo-Saxon vitalism began to be eroded and now 'British doom is close to its maturation, in the conclusion of this racial circularity. ${ }^{77}$ The Commonwealth system, once again a Tudor formula, represented the centrifugal forces that were reawakening once again. The consequence was that Britain was

giving up the cores of its imperial economic potential; the loss of the most essential ocean bases; the abandonment of the most important South American and of the special systems of control on the movements of the traffic between Great Britain and the Commonwealth. ${ }^{78}$

These were only some among the most obvious signs of the destruction of the British Empire. Such a rapid redefinition of the positions of power could seem incredible, but it was nothing but 'the convulse contraction of an ethnic aggregation with no roots in history inside its own atomistic microcosm.' The Anglo-Saxon people defined itself, Savelli wrote, 'in this paralysis, which is biological more than moral, in this wooden involution caused by an ethnical experience fastened between the shapelessness [sic] of insufficiency and the abnormality of solitude.'

\section{The Punic Race: The Mediterraneanist-Evolian Definition of the Racial Inferiority of the Anglo-Saxons}

The Mediterraneanists' offensive peaked with a long article written by Aldo Modica (who had, in June 194I, wrote in La Difesa the previously heretical concept of the lack of interdependence between the Italian Mediterranean and Germanic civilisations), which discussed a topic developed through five issues of the magazine in a series of articles entitled 'The Racial Inferiority of Anglo-Saxons. ${ }^{79}$ While in the article Modica carefully avoided openly condemning Italy's Germanic allies as an inferior or inherently flawed race, he still maintained that the flaws of the Anglo-Saxons came from traits that were typical of the Nordic Germanic race. Another remarkable feature of the article is how Modica combined his Lamarckian and anti-Germanic attitude, typical of the Mediterraneanist worldview, with continuous nods to the Evolian, Spiritual-Nordicist mythology. Modica's insistence on Aryanism, heroism, tradition and warrior castes is a clear sign that the author was doing his best to please the then ascending Evolian faction, while at the same time attempting to attack his old biological Nordicist rivals. 
Anglo-Saxons' human individualism, due to inferior biology, had made them unable to evolve from a 'brute association' of individualisms, a 'biological flaw' present in the Teutonic racial stock but exalted in the Anglo-Saxon ethnicities. The anti-Germanic tone of Modica's claim is striking, even if he added that the 'current Germanics' had managed to 'eliminate and put under a rigid discipline' those traits thanks to 'superior and diverse biological gifts' like physiology and spiritualism. The hypertrophic personality of every Anglo-Saxon individual made him unable to express a true sociality, understood as a mutual limitation of the individualisms for a 'natural goal.'

Having to compensate for their biological inferiority, the Anglo-Saxons like some predators in nature - paraded an excessive display of power, which impressed some un-individualistic peoples. Under this light, 'their formal superiority was a consequence of their substantial inferiority.' Moreover, thanks to their economic worldview and material means, they succeeded in spreading their barbarous 'conventional values' among races once ruled by the typically Aryan heroic nobility and those biologically superior to them. ${ }^{80}$ To demonstrate the inferiority of the Anglo-Saxons to the Nordic-Aryan race, as well as to the Mediterranean-Aryan race, due to their 'economic, antiheroic and antivital character' and their inability to organise themselves on any meaningful level, Modica again used examples from the animal world, describing the English as a beast that was intelligent but unable to organise himself in social complexes, hence inferior to other species. ${ }^{81}$

According to him, the most developed human races shared these superior traits. Different from races like the Neanderthals, 'proto-Aryan' humanity had developed heroic-agricultural and heroic-hunter civilisations that prised 'biological values,' heroism and sociality. While the descendants of the Neanderthals - Punic-Phoenicians, Jews, Anglo-Saxons - were lacking a racial consciousness and were just able to elaborate 'nonbiological' values to create civilisations dominated by hedonism and wealth, the proto-Aryans were instead builders of great civilisations united by a common blood and mysticism. Theirs were, among others, the Indian, Mesopotamian, Egyptian (before the negroid-Jewish contamination), Greek, Roman and some Germanic civilisations. They had

'Nordic-Dalic' traits. These two kinds of humanity fought each other through the centuries: these two 'biotypes,' corresponding to the two great racial 'lines,' have hence been fighting because of vital necessity since prehistory, and they still do. ${ }^{82}$ 
As for the ancestors of the racial elements existing in Britain (proto-Aryan Hybernians, Gaelics and Britons), they were so diverse that it had been impossible for them to create a 'national union based on blood and tradition,' their linkage being based only on individuals' common interests. Individualism made the Gaelics and Britons inferior to the Nordic race and unable to resist the invasion of the however inferior Anglo-Saxons ${ }^{83}$ Here, Modica feebly attempted to differentiate the Anglo-Saxons from the Germans, writing that

the German Saxons [who lived on the Elba], who constituted together with the Franks and the Swabians the German group, distinguished from the Anglo-Saxon-Frisian also according to [an] ethnical point of view, lived in the land that we today call Holstein. ${ }^{84}$

The Angles were the group that had a major role in the conquest and colonisation of what they later called 'Engla-Lond.' Once in Britain, these peoples had experienced an involution influenced by several factors that Modica identified, nebulously enough, as 'the mutation of the surrounding biospheric environment,' the 'physical and psychocultural mongrelisation' and 'the change of culture in its ethno-racial meaning from the culture relative to the original environment.' This new 'bioanthropological line' entailed physical differences and mutations, which were proof of the racial inferiority of the Anglo-Saxon racial group. ${ }^{85}$

The Anglo-Saxons had in themselves a concentration of 'the negative characters common to the Nordic groups' and 'represented a deteriorated branch of the greater Indo-Germanic stock.' Their distinctive features were individualism and insufficient emotivism, sexual morbidity, moral coldness, egoism, aggressivity. Typical of this ethnicity was also a good and analytical memory (traits that, again, they shared with the Jewish race), but very little ability for abstraction and synthesis. ${ }^{86}$

Once again, Modica wavered between an absolution of the Germanic branch of the Nordic race and its condemnation. Indeed, he wrote that what separated the psyche of the Germanic and Anglo-Saxon branches was that the biology of the former caused 'psychic explosions and improvise cruelty.' However, the conclusion of the article stated that the biological inferiority of the Anglo-Saxons was typical of the racial branch to which they belonged. Whether Modica intended to include the Germanics in this sentence is open to speculation.

While Modica's article was long and often confused, it is a remarkable example of how far Italian racists' anti-British criticism had gone. In his Evolian division of humanity into two, ever struggling groups, Modica had located the 
Anglo-Saxons in a place of irredeemable anthropological difference. No peace could exist with a people whose values were inherently opposed to the ones of the Mediterranean-Aryan-Italian civilisation. The obvious implication of Modica's article was that Britain was indeed the New Carthage, to be annihilated like its Punic predecessor. Indeed, the article concluded that it was necessary 'to defend [ourselves] with prudency from the Anglo-Saxons and fight them so to demolish the strength of their substantial, and naturally not remediable, weakness. ${ }^{87}$

While he considered the Anglo-Saxons biologically inferior and inherently dangerous, his article was not yet the most violent condemnation of the role and nature of the Anglo-Saxons to appear in La Difesa before the end of both the magazine and the regime. In January 1943, during the increasingly desperate battle for Tunisia, Armando Tosti wrote an article entitled 'The Anglo-Saxon Race Against Europe.' There, he attacked the Anglo-Saxons and, more broadly, the 'dolichocephalic-blonde races' that had developed in the polar regions, where the long periods of darkness alternated with long periods of light. In such conditions, every family lived far and isolated from others, in houses only enlightened by the hearths, so that 'a development in each individual of a tendency to solitude, misanthropy, retreat into himself, even a lack of cohesion with its own familiar group' appeared natural. During the period of darkness the whole group was isolated, 'surrounded by the unknown and by mystery, [while] during the period of light the husbands, the fathers, the eldest sons abandon the family and leave for fishing in new, far lands.' The natural consequence was the emergence of 'an exaggerated individualism, the feeling of being weak in front of nature' and, what was worse, the moral weakness 'of the race that, enclosed in its fierce egoism, proves to be still today unable to absolve any duty of European solidarity.' In Tosti's view, particularly remarkable in light of his prolific anti-Semitism, it was Britain, even more than the Jews, who had been the cause of all Europe's miseries:

England, this carboniferous island, immersed in the mist and beaten by the waves, monotone in its landscapes and poor in its vegetation, inhabited originally by the Celts, by the Scandinavians and eventually by the Germanics, civilised by the French-Normans, England is, since centuries, because of its greediness for wealth, the cause and origin of every European perturbation and calamity. ${ }^{88}$

Even more than Modica's, Tosti's article combined a strongly Mediterraneanist and Lamarckian point of view with a clear anti-German attitude. ${ }^{89}$ It is easy to imagine how infuriated Landra would have been by reading opinions that 
were so diametrically opposed to his own in the magazine that was once the main voice of the biological Nordicist faction.

Racism was only institutionalised in Fascist Italy in the second half of the 1930s. The late and difficult attempts to develop a comprehensive Fascist racial theory eventually failed, under the weight of the differences between the rival racist factions and the misfortunes of war. In such a context, a precise and definitive hierarchy of races was never really developed and, even more than in the Nazi case, racial criticism of other peoples depended on many, usually expedient, factors. The consequence of this, and of the fact that by the time anti-British propaganda started to appear in racist Fascist media, Italy was moving closer to a country that was supposedly racially close to Britain, was that a purely racial criticism of the British people only appeared quite late, well into the war.

It was far easier to identify in the British nation (or in general in the concept of the 'decadent West') the flaws of the internal enemy that Mussolini considered the real bane of Fascism and Italy: the bourgeois class. In Mussolini's perception, the bourgeoisie was either Fascist or actively anti-Fascist and represented the kind of Italian that had to be replaced by the 'Fascist New Man.' The Duce's obsession with the health of the nation made the identification between the West and bourgeois class easier. The British (and the French until their defeat in summer 1940) then became the example of what Fascist Italy should both fight and fear. This kind of anti-British discourse had, then, the advantage of targeting both the external and internal enemies of Fascism. However, while such articles used what was then considered anthropological analysis of the British national character to criticise Britain, they still did not adopt a truly 'racial' approach, being closer to the usual habit of the Italian Fascists to judge according to national stereotypes..$^{90}$ Gradually, as the war continued and Italy's fortunes dimmed, a more overtly racial discourse gained traction, without, however, ever completely replacing the other, 'anthropological' approach. Predictably, given the extreme fluidity and fragmentation of the world of racist Italian thinkers, their response was diverse and conflictual. The Nordicist faction, which had previously been appreciative of the British attitude to racial superiority in the colonies, split between those, like Cipriani, who simply ignored or denied the Germanic racial character of the Anglo-Saxons, and those who, like Landra, never accepted the notion of the Anglo-Saxon race as inferior or racially incompatible with European civilisation. The Mediterraneanist (and, later Evolian) faction took advantage of the situation to gain ideological ammunition for their anti-Nordic crusade. In this case, it seems that Britain had become a useful target for those among the anti-Nordicist racists who wanted to attack Germany 
and the Nordic myths, without risking criticising its 'Nordic cousin.' This kind of racial analysis of the British, which would rather use the term Anglo-Saxons, often tried to explain the materialistic, individualistic and archaic nature of British society by identifying its biological reasons. The most common tropes of these analyses were the Anglo-Saxons' limited intellect, pathologically twisted perception of reality and their inherent inability to limit their own individualisms to form a true society, to the point of justifying a classification of the Anglo-Saxon race as inferior. Mussolini himself seems to have assimilated some of these notions, for he stated a few months before his fall that the British people's strength was its own stupidity. This, he claimed, was 'not a figure of speech, but a real state of the English intellect, slow and dull. ${ }^{91}$

It should be kept in mind that magazines such as La Difesa, like the other vanguards of Italian racism, while widely distributed, failed to influence the majority of the Italian population. ${ }^{92}$ After the first months, the magazine's sales rapidly declined. La Difesa, like the rest of the racist press, then became dependent on state subsidies. ${ }^{93}$ Furthermore, it does not appear likely that the Anglophobia that could be displayed by the Italian people was key in the racial debate about the English race. Extreme racial criticism of the British and American peoples was undoubtedly only ever undertaken by a minority. An analysis of the racist anti-British propaganda does, however, tell us about the regime, both in better understanding the dynamics of the racist debate it led, and the depths of delusion reached by certain segment of Fascist propaganda under the shadow of defeat. 